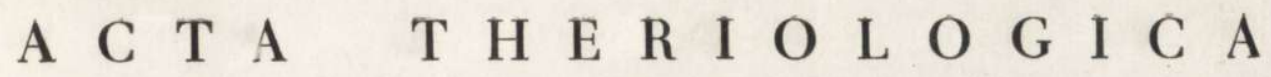 \\ VOL. X, 16: 225-228. \\ BIAEOWIEŻA \\ 30.IX.1965
}

Andrzej M Y R C H A

\section{Length and Weight of the Alimentary Tract of Apodemus flavicollis (M elchior, 1834)}

[With 3 Tables]

Investigation was made of the length and weight of the alimentary tract in 100 individuals of $\mathrm{A}$. flavicollis ( $57 \sigma^{\top} \sigma^{\top}$ and 43 \% 9 ). Considerable increase in these indices was found in pregnant and lactating females.

Very little research has hitherto been carried out on the morphology of the alimentary tract of Apodemus flavicollis (M e l $\mathrm{ch}$ io r, 1834). Only $\mathrm{N}$ a u mov (1948) gives data on the length of the intestines of this mammal, and S a blin a (1953) on the weigth of its alimentary tract. As the latter author weighed the intestines and stomach of the animals examined together with the foodstuffs they contained, the results she gives are very inexact. The histological structure of the alimentary tract of this rodent has been more thoroughly examined (L u p p a, 1958a; 1958b; 1961).

In the investigations made of Clethrionomys glareolus ( $\mathrm{S} \mathrm{ch} \mathrm{reber,}$ 1780 ), it was found that the length and weight of the intestines increase in females during pregnancy and lactation ( $\mathrm{M} \mathrm{y} \mathrm{r} \mathrm{h} \mathrm{a,1964).} \mathrm{In} \mathrm{order} \mathrm{to}$ determine whether this is a more general phenomenon occurring in other species of mammals also, it was decided to investigate the variations, depending on the physiological condition of the individuals examined, in the morphological indices of the alimentary tract of $A$. flavicollis, a representative of a different family of rodents.

Morphological examination of the alimentary tract of $A$. flavicollis was made for animals captured during the period from July to December 1963 within the Białowieża National Park, in a Querco-Carpinetum stachyetosum $\mathrm{R}$. Tx. biotope. A total of 100 rodents were examined $\left(57 \sigma^{7} \sigma^{7}\right.$ and 43 우). The animals were caught in live-traps and taken to the laboratory where, after making general measurements of the body, they were dissected and the alimentary tract excised, with the exception of the oesophagus. The length of the various sections of the intestine was 
measured on a glass plate, on to which normal saline solution was poured in order to avoid stretching the walls of the tract. After measuring the intestines and stomach, and removing all traces of food from them, they were weight on an automatic scale with acuracy to $0.1 \mathrm{mg}$. Calculation was made for each animal of the relation of length of intestine and its various sections to body length, and the length and weight of each part of the alimentary tract expressed in percentages. Sexual activity of females was determined on the basis of the appearance of the uterus, presence of e mbryos and corpora lutea and the size of the milk gland. Statistical analysis of the results obtained was made by means of the $t$-Student test for the difference between mean values for two independent groups.

Table 1.

Mean values of indices of the length of intestines in A. flavicollis.

\begin{tabular}{|c|c|c|c|c|c|c|c|c|c|c|c|c|}
\hline \multirow{2}{*}{ Sex } & \multirow{2}{*}{$\mathrm{N}$} & \multicolumn{4}{|c|}{ Length of intestine in $\mathrm{cm}$. } & \multicolumn{3}{|c|}{$\begin{array}{c}\text { \% of total length } \\
\text { of intestine }\end{array}$} & \multicolumn{4}{|c|}{$\begin{array}{l}\text { Ratio of length of intes- } \\
\text { tines to length of body }\end{array}$} \\
\hline & & Small & Large & Caecum & Total & Smell & Large & Caccum & Small & Large & Caecum & Total \\
\hline 888 & 57 & 35.8 & 13.4 & 4.1 & 53.3 & 67.2 & 25.2 & 7.6 & 3.41 & 1.28 & 0.39 & 5.07 \\
\hline$q q$ & 43 & 38.4 & 14.1 & 4.7 & 56.7 & 67.5 & 24.6 & 7.9 & 3.78 & 1. 37 & 0.43 & 5.58 \\
\hline
\end{tabular}

Table 2.

Mean values of weight indices of the alimentary tract in A. flavicollis

\begin{tabular}{|c|c|c|c|c|c|c|c|c|c|c|c|}
\hline \multirow[b]{2}{*}{ Sex } & \multirow[b]{2}{*}{ N } & \multicolumn{5}{|c|}{ Weight of intestine in $\mathrm{g}$. } & \multicolumn{5}{|c|}{ \% of total body weight } \\
\hline & & Small & Lerge & Caecum & Stotnach & Total & Sina11 & Lerge & Caecum & Stomach & Tote: \\
\hline A8 & 57 & 0.6623 & 0.2762 & 0.1661 & 0.2880 & 1.3925 & 2.07 & 0.85 & 0.50 & 0.91 & 4.35 \\
\hline $q$ & 43 & 0.8099 & 0.3276 & 0.1714 & 0.3425 & 1.6524 & 2.72 & 1.07 & 0.57 & 1.13 & 5.49 \\
\hline
\end{tabular}

The mean values of indices of length and weight of the intestines for A. flavicollis are given in Tables 1 and 2. Statistical analysis of the data given did not reveal significant differences in the length and weight of the alimentary tract of males and females of this species. A statistically significant difference was obtained only when comparison was made of the percentage of weight of intestines of the total body weight of the animals. This index is $1.15 \%$ greater in females.

The results obtained for the $A$. flavicollis population at Białowieża agree ir principle with the data given by $\mathrm{N}$ a u m o v (1948), which he obtained from his investigations in the Tula district. The rodents which this author 
examined differ only as to the slightly greater percentage of the caecum in the total length of intestincs.

There were 25 sexually active and 18 inactive animals among the 43 q 우 of A. flavicollis examined. Statistically significant differences between these two groups of females were found in relation to the total length of intestines and weight of the whole alimentary tract and its various sections. No statistically significant differences were, however, obtained in the length and weight of intestines when sexually inactive females and males of this species were compared (Table 3 ).

$\mathrm{S}$ a blin a (1953), who weighed the intestines of $A$. flavicollis together with their food contents, also demonstrated the increase in the weight of the intestines in sexually active females. In one of the study periods (March 1946) she found maximum weight of the alimentary tract in males with developed testes and seminal ducts. Acorns and nuts were found to form a considerable part of the food of $A$. flavicollis during the periods in which reproducing individuals predominated in the population examined.

Table 3.

Length and weight of the alimentary tract in sexually active and in non-reproducing females of A. flavicollis.

\begin{tabular}{|c|c|c|c|c|c|c|c|c|c|c|}
\hline & \multirow{2}{*}{ N } & \multicolumn{4}{|c|}{ Length of 1ntest1ne $1 \mathrm{n} \mathrm{cm}$. } & \multicolumn{5}{|c|}{ We1ght of intestine in $\mathrm{g}$. } \\
\hline & & Small & Large & Caecum & Total & Sma11 & Large & Caecum & Stomaoh & Total \\
\hline $\begin{array}{l}\text { Sexually } \\
\text { 1nactive }\end{array}$ & 18 & 36.1 & 13.2 & 4.8 & 53.7 & 0.6774 & 0.2731 & 0.1451 & 0.2849 & 1. 3825 \\
\hline $\begin{array}{l}\text { Sexually } \\
\text { aotive }\end{array}$ & 25 & 40.1 & 14.7 & 4.4 & 59.2 & 0.9424 & 0.3827 & 0.1978 & 0.4002 & 1.9223 \\
\hline$t_{0.05}$ & & & & & 8.0170 & 3.2716 & 3.8188 & 2.1867 & 3.8691 & 5.2408 \\
\hline
\end{tabular}

The above author therefore reached the conclusion that the state of the genital organs depends on the kind of food eaten. This conclusion is, however, burdened with error resulting from the different weight of the foodstuffs, depending on the quality of the components of the food eaten by the animals examined.

The results obtained in this study agree with the data obtained for rats (F e ll, S mith \& C am pbe 11, 1963) and for C. glareolus (M y r cha, 1964), and from evidence that elongation and hypertrophy of the walls of different sections of the alimentary tract take place during pregnancy and lactation in females of this species also.

$\mathrm{Ka} \mathrm{czmarski}$ (1965) found that the food requirements of lactating females of $C$. glareolus are almost doubled. This increase is due to intensification of the physiological processes in the females organism during reproduction. The organism compensates difficulty in assimilating the increased amount of food by an increase in the digestive capacity of the 
alimentary tract, which is expressed in an increase in the length and weight of the intestines in sexually active females. There are, however, reversible changes solely connected with the reproduction period of the rodeints.

\section{REFERENCES}

1. Fell B. F., Smith K. A \& C a m p bell R. M., 1963: Hypertrophic and hyperplastic changes in the alimentary canal of the lactating rat. J. Pathol. Bacteriol. $85,1 \cdot 179-188$.

2. K a z marski F., 1965: Bioenergetics of the pregnancy and lactation in the bank vole, Clethrionomys glareolus (S c h r e b e r). (Msc.)

3. Luppa H. W., 1958: Ein Beitrag zur Kenntnis des Vorderdarmes der Bisamratte (Ondrata zibethica L.) und einiger muriden Nager [Microtus arvalis $\mathrm{P}$ a 11.; Arvicola terrestris L.; Clethrionomys glareolus $\mathrm{S} \mathrm{ch} \mathrm{reb}$.; Apodemus flavicollis ( $\mathrm{M} \mathrm{e} 1 \mathrm{c}$ h.)]. Wiss. Z. M.-Luther Univ. Halle., Math. Nat., 7, 2: 249-266.

4. L u p p a H. W., 1958: Zur Histologie und Kohlehydrathistochemie des Dünndar. mes der Bisamratte (Ondatra zibethica L.) im vergleich $\mathrm{zu}$ einiger muriden Nagern. Wiss. Z. M.-Luther Univ. Halle. Math. Nat. 8, 1: 87-108.

5. Lu p p a H. W., 1961: Makroskopische, mikroskopische und topochemische Untersuchungen an der Schleimhaut des Enddarmes der Bisamratte (Ondatra zibethica L.) und einiger muriden Nager. Z. mikroskop.-anatom. Forsch. 67, 4: 610-631.

6. My rch a A:, 1964: Variations in the length and weight of the alimentary tract of Clethrionomys glarecilus ( $\mathrm{S} \mathrm{ch} \mathrm{re} \mathrm{be} \mathrm{r,} \mathrm{1780).} \mathrm{Acta} \mathrm{theriol.} \mathrm{9,} \mathrm{10:} \mathrm{139-148.}$

7. N a u mov N. P., 1948: Očerki sravnitelnoj ekologii myševidnyh gryzunov. Izd. Ak. Nauk SSSR. : 1-204. Moskva-Leningrad.

\&. S a b lin a T. B., 1953: Ekologija želtogorloj myši v zapovednike "Belovežskaja pušča". Tr. In-ta morf. život. im. A. N. Severcova. 9: 231-249. Moskva.

Polish Academy of Sciences,

Mammals Research Institute,

Białowieża, woj. Białystok.

Andrzej MYRCHA

\section{DEUGOSĆ I CIĘŻAR PRZEWODU POKARMOWEGO APODEMUS FLAVICOLLIS (M EL C H I O R, 1834)}

\section{Streszczenie}

Badania morfologiczne przewodu pokarmowego A. flavicollis przeprowadzono na

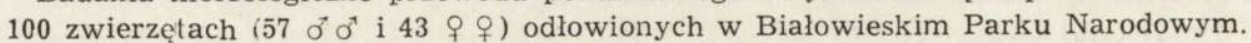
Po wypreparowaniu przewodu pokarmowego (bez przelyku) mierzono dlugość poszczególnych odcinków jelit, a nastẹpnie po dokładnym oczyszczeniu z treści pokarmowej jelita i żołądek ważono. Określono także aktywność płciową wszystkich samic. Otrzymane wyniki pozwalają stwierdzić, ̇̇e:

1. Długość i ciężar przewodu pokarmowego A. flavicollis są jednakowe u samców i nieaktywnych plciowo samic tego gatunku (Tab. 1, 2).

2. U samic aktywnych płciowo następuje wzrost długości i ciężaru jelit (Tab. 3), co związane jest ze zwiększonym zapotrzebowaniem pokarmowym tych zwierząt 4: okresie ciąży i laktacji. Jest to zjawisko okresowe i odwracalne. 